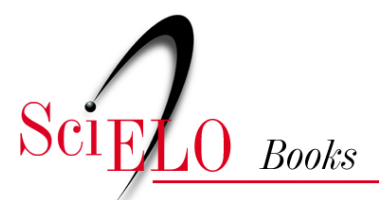

\title{
25. Eijkman, o Detetive do Beribéri
}

\author{
Joffre Marcondes de Rezende
}

REZENDE, J. M. Eijkman, o Detetive do Beribéri. In: À sombra do plátano: crônicas de história da medicina [online]. São Paulo: Editora Unifesp, 2009, pp. 237-240. História da Medicina series, vol. 2. ISBN 978-85-61673-63-5. https://doi.org/10.7476/9788561673635.0026.

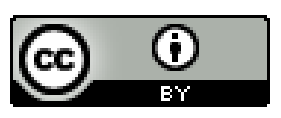

All the contents of this work, except where otherwise noted, is licensed under a Creative Commons Attribution 4.0 International license.

Todo o conteúdo deste trabalho, exceto quando houver ressalva, é publicado sob a licença Creative Commons Atribição 4.0.

Todo el contenido de esta obra, excepto donde se indique lo contrario, está bajo licencia de la licencia Creative Commons Reconocimento 4.0. 


\title{
25
}

\section{Eijkman, o Detetive do Beribéri}

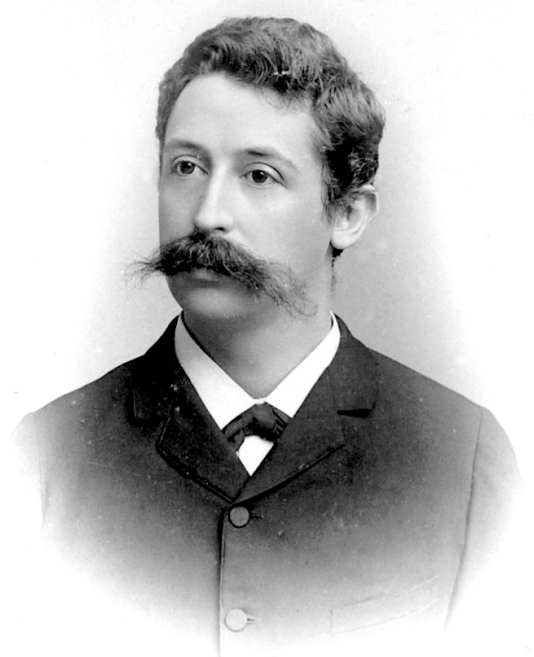

Christiaan Eijkman (I858-I930).

\begin{abstract}
A descoberta da etiologia do beribéri por Eijkman, em I889, encerra lances próprios de um enredo policial. O beribéri era conhecido, desde antes de Cristo, na China e países do Oriente.

O primeiro relato científico no Ocidente se deve a Bontius (I 592-I63I), quem descreveu casos por ele observados no Sudeste asiático. Em seu trabalho, escrito em latim e publicado onze anos após sua morte, usou a denominação de "beri-beri”" (Major, I954, p. 537).

O nome beribéri, adotado na terminologia médica, provém do cingalês (sinhalese), língua originária da Índia e atualmente uma das línguas oficiais do Ceilão (Sri Lanka), onde é falada por cerca de onze milhões de pessoas. Nessa língua, o superlativo é formado pela repetição da palavra. Beri quer dizer fraco e beri-beri, extremamente fraco (Katzner, I986, p. 201).

No Japão a doença era chamada kakke e acometia principalmente os marinheiros. O barão de Takaki, entre I 882 e I 884 , conseguiu reduzir sua incidência na marinha japonesa melhorando a alimentação nas embarcações com a introdução de outros pratos além do arroz polido.
\end{abstract}


No século XIX, a Indonésia era possessão holandesa e o governo holandês, preocupado com as doenças que grassavam em suas colônias, especialmente o beribéri, decidiu enviar uma comissão para estudar in loco o beribéri. Pensava-se que se tratasse de uma doença infecciosa e por isso os membros dessa comissão foram antes realizar um estágio em Berlim, no laboratório de Koch, para dominar as técnicas bacteriológicas em uso. Vivia-se uma época de novas e sucessivas descobertas de bactérias patogênicas, responsáveis por doenças há muito conhecidas e de causa ignorada. Lá encontraram-se com Christiaan Eijkman, que estivera anteriormente em Java e que se mostrou igualmente interessado no estudo do beribéri. Eijkman foi incorporado à comissão e voltou à antiga colônia holandesa em missão oficial.

Em I 886 os membros da comissão desembarcaram na ilha de Java, em Batávia (hoje Jacarta, capital da Indonésia), onde desenvolveram suas pesquisas. Descreveram o curso clínico da doença, especialmente em relação às suas manifestações neurológicas, e isolaram um micrococo que acreditaram fosse o agente infeccioso causador do beribéri. Eles retornaram à Holanda, deixando Eijkman em Batávia para continuação das pesquisas (Carpenter, 2000, pp. 32-34).

Eijkman foi indicado para diretor da Escola Médica de Java e prosseguiu suas observações sobre o beribéri. Logo percebeu que o micrococo isolado não poderia ser o agente causal do beribéri, pois não preenchia os postulados de Koch, ou seja, o isolamento do germe, a reprodução experimental da doença por ele causada e o seu reisolamento.

Nesse ínterim, observou o aparecimento de uma doença no biotério do laboratório, onde os frangos apresentavam sinais de uma polineuropatia grave, caracterizada por fraqueza muscular, incapacidade de manter-se de pé ou de abrir as asas, inapetência e finalmente morte. Chamou a essa doença polyneuritis gallinarum e considerou-a equivalente ao beribéri.

Inesperadamente, as aves acometidas da doença e que ainda estavam vivas começaram a melhorar e os sintomas desapareceram completamente. Eijkman, qual um detetive, começou a procurar uma explicação para essa recuperação espontânea das aves e teve sua atenção despertada para a alimentação. No período de manifestação da doença os frangos estavam sendo tratados com sobras da cozinha dos oficiais do hospital militar, onde se usava arroz polido da melhor qualidade. A melhora e recuperação dos frangos 
havia coincidido com a mudança na ração. Houve troca de cozinheiro e o novo cozinheiro entendeu que era um desperdício destinar alimentos da cozinha dos oficiais para galináceos, que passaram, então, a receber alimentos de pior qualidade, inclusive arroz despolido. Como contraprova de sua hipótese, Eijkman realizou o experimento decisivo: alimentou um grupo de frangos com arroz polido e outro grupo com arroz despolido. Somente as aves alimentadas com arroz polido desenvolveram polineurite.

$\mathrm{Na}$ etapa seguinte, Eijkman isolou da cutícula do arroz uma substância solúvel na água e no álcool, a que chamou de princípio antineurítico. Com ela não só prevenia, como curava a polineurite dos frangos. Restava demonstrar que a causa do beribéri humano era a mesma da polineurite das aves.

Eijkman foi informado de que em algumas prisões da colônia usava-se arroz polido e em outras arroz despolido. Os dados obtidos em IOI prisões que albergavam cerca de trezentos mil presos permitiram a Eijkman concluir que a prevalência do beribéri era trezentas vezes maior nas prisões que usavam o arroz polido em relação às que não o usavam (Minkoff, I99I, pp. 297-302).

Eijkman admitiu a existência de uma toxina no arroz polido, a qual seria neutralizada pelo princípio antineurítico por ele isolado e este foi o seu único equívoco.

Coube a Grijns, que sucedeu Eijkman na direção do laboratório em Batávia, a formular a teoria de que o beribéri seria causado, não por uma toxina, mas pela carência de uma substância existente na cutícula do arroz. A natureza química desta substância foi determinada em I9I I por Casimir Funk, quem cunhou a palavra vitamina, formada do latim vita, vida + amina, por ser um fator acessório da alimentação, essencial à vida.

A vitamina contida na cutícula do arroz foi isolada por Jansen e Donath em I926, que lhe deram o nome de aneurina, e finalmente sintetizada em I936, simultânea e independentemente por Williams e Cline, nos Estados Unidos, e Andersag e Westphal, na Alemanha. Recebeu o nome de tiamina por conter enxofre em sua molécula (do grego thio, enxofre) (Villela, Bacila e Tastaldi, I966, pp. 200-20I).

Christiaan Eijkman recebeu o prêmio Nobel em I 929 por seus trabalhos sobre o beribéri, juntamente com Frederick Hopkins, este último por suas pesquisas sobre os "fatores acessórios da alimentação", que correspondiam às vitaminas. 
No Brasil, as primeiras referências a uma doença identificada ao beribéri datam do final do século Xviı e se devem a Alexandre Rodrigues Ferreira, naturalista baiano cognominado "Humboldt brasileiro".

Ferreira, em viagem pela região amazônica, registrou o encontro de enfermos acometidos de "intensa fraqueza, perturbações circulatórias, edemas e polineurite" (Santos Filho, I991, p. 263).

Silva Lima (I866, I 868 e I 869), um dos integrantes da chamada escola tropicalista baiana, estudou detalhadamente o beribéri na Bahia. Entre os anos de I866 e I869 publicou uma série de artigos na Gazeta Médica da Babia, todos com o mesmo título: "Contribuição para a História de uma Moléstia que Reina Atualmente na Bahia sob a Forma Epidêmica e Caracterizada por Paralisia, Edema e Fraqueza Geral". Descreveu o quadro clínico com grande riqueza de observações, estabeleceu o diagnóstico diferencial com a pelagra e registrou dados anatomopatológicos de necrópsia. Classificou o beribéri em três formas clínicas: forma polineurítica, forma edematosa e forma mista.

Em I 872, Silva Lima reuniu todos os seus trabalhos sobre beribéri em um volume sob o título Ensaio sobre o Beribéri no Brasil, que se tornou um clássico da literatura médica brasileira.

Após os estudos de Silva Lima, seguiram-se muitas outras publicações de autores brasileiros sobre o beribéri.

\section{Referências Bibliográficas}

Carpenter, K. J. Beriberi, White Rice and Vitamin B. Berkeley, University Press, 2000. Katzner, K. The Languages of the World. London, Routledge \& Kegan Paul, I986. Major, R. H. A History of Medicine. Oxford, Blackwell Scientific Publications, I954. Minkoff, E. C. “Christiaan Eijkman-I929”. In Magill, F. N. The Nobel Prize Winners. Physiology or Medicine. Pasadena, Salem Press, I991.

Santos Filho, L. História Geral da Medicina Brasileira. São Paulo, Hucitec/Edusp, I99I. Silva Lima, J. F. “Contribuição para a História de uma Moléstia que Reina Atualmente na Bahia sob a Forma Epidêmica e Caracterizada por Paralisia, Edema e Fraqueza Geral”. Gazeta Médica da Bahia, I, I 866, pp. I Io-I I3, I25-I28, I38-I39; 3, I 868, pp.55-56, 85-87, I09-III; 3, I869, pp. I33-I35, I45-I47.

Villela, G.; Bacila, M. \& Tastaldi, H. Bioquímica. Rio de Janeiro, Guanabara Koogan, I966. 